\title{
Antibacterial substances of sponges, Agelas tubulata and Phyllospongia sp., from Manado Bay, against the growth of several bacterial strains
}

\section{Senyawa antibakteri spons, Agelas tubulata dan Phyllospongia sp., dari Perairan Teluk Manado, terhadap pertumbuhan beberapa strain bakteri}

\author{
Nani Ingrid J. Undap ${ }^{1 *}$, Deiske A. Sumilat ${ }^{2}$, and Robert Bara ${ }^{2}$ \\ ${ }^{1}$ Program Studi Magister Ilmu Perairan, Fakultas Perikanan dan Ilmu Kelautan, Universitas Sam Ratulangi. \\ Jl. Kampus Unsrat Kleak,Manado 95115, Sulawesi Utara, Indonesia. \\ ${ }^{2}$ Fakultas Perikanan dan Ilmu Kelautan, Universitas Sam Ratulangi. Jl. Kampus Unsrat Bahu, Manado 95115 , \\ Sulawesi Utara, Indonesia. \\ *E-mail: ingrid_undap@yahoo.com
}

\begin{abstract}
Agelas tubulata and Phyllospongia sp. are marine sponge that contain active compounds that have potential to be antibacterial, anticancer and antifungal which have not been used. This study was aimed to examine the sponge extracts which inhibit bacterial growth, i.e. Pseudomonas aeruginosa, Proteus mirabilis, Staphylococcus aureus, Escherichia coli, S. saprophyticus and to analyze the active fraction of the antibacterial component using bio-autographic method. Agelas tubulata and Phyllospongia sp. were collected from Manado Bay and method used in the study was Agar Diffusion Method. Results showed that A. tubulata and Phyllospongia sp. extract had antibacterial activity against all 5 bacteria tested. A. tubulata extract had inhibition zone with broader spectrum than that of Phyllospongia sp. extract, while Phyllospongia sp. has specifity for $P$. mirabilis.
\end{abstract}

Keywords: Agelas tubulata; Phyllospongia sp.; extract of sponges; antibacterial.

Abstrak: Agelas tubulata dan Phyllospongia sp. merupakan spesies spons laut yang mengandung senyawa aktif yang berpotensi antibakteri, antikanker dan antijamur yang belum banyak dimanfaatkan. Penelitian ini bertujuan untuk menguji ekstrak spons laut yang menghambat pertumbuhan 5 bakteri yaitu Pseudomonas aeruginosa, Proteus mirabilis, Staphylococcus aureus, Eschericia coli dan Staphylococcus saprophyticus dan menganalisis fraksi aktif antibakteri melalui teknik bioautografi. Spesies spons laut A. tubulata dan Phyllospongia sp. diambil dari Perairan Pantai Malalayang Manado. Metode yang digunakan yaitu metode difusi agar. Hasil dari penelitian ini, yaitu ekstrak $A$. tubulata dan Phyllospongia sp. mempunyai aktivitas terhadap 5 bakteri uji. Ekstrak $A$. tubulata memiliki daya hambat dengan spektrum yang lebih luas dibandingkan ekstrak Phyllospongia sp. sedangkan ekstrak Phyllospongia sp. memiliki spesifitas terhadap bakteri P. mirabilis.

Kata-kata kunci: Agelas tubulata; Phyllospongia sp.; ekstrak spons; antibakteri.

\section{PENDAHULUAN}

Berbagai penelitian menunjukkan bahwa biota laut memiliki potensi yang sangat besar dalam menghasilkan senyawa-senyawa aktif yang dapat digunakan sebagai bahan baku obat. Sejak tahun 1980-an, perhatian dunia pengobatan mulai terarah kepada berbagai macam biota laut sebagai sumber daya yang sangat potensial. Beberapa biota laut yang diketahui menghasilkan senyawa aktif antara lain spons, moluska, briozoa, tunikata, dan lain-lain (Blunt, 2012).

Salah satu jenis organisme bentik yang berpotensi cukup besar dan berpeluang mengan- dung senyawa aktif adalah spons. Spons merupakan hewan laut yang penyebarannya sangat luas di perairan laut sampai pada kedalaman 50 meter. Sejauh ini tercatat sekitar 15.000 spesies spons laut di seluruh dunia (Denning, 2006).

Spons (Porifera), sering disebut juga sebagai bunga karang, merupakan hewan primitif yang multiseluler, oleh karena itu sering disebut sebagai metazoa. Beberapa jenis tidak mempunyai mulut dan saluran cerna atau tidak mempunyai sistem organ yang lengkap. Badannya berbentuk pori yang berisikan satu atau lebih kafitas berflagella yang dinamakan choanocytes. Hewan ini termasuk organisme yang unik karena kehidupannya bersama 
dengan mikroba yang saling bergantung satu dengan yang lain atau simbiose positif (Rompas, 2011). Diduga mikroorganisme simbion ini terlibat dalam biosintesis senyawa senyawa aktif yang terdapat dalam spons ini (Proksch, 2002).

\section{MATERIAL DAN METODA}

Penelitian ini dilaksanakan dengan menggunakan metode eksperimental. Spons, yang diambil dari perairan Pantai Malalayang, Manado, Sulawesi Utara, di kedalaman 5-16 m, dipotong kecil-kecil berbentuk kubus dan ekstraksi dengan cara maserasi dalam larutan etanol $95 \%$.

\section{Pembuatan media Brain Heart Infusion (BHI)}

Media BHI ditimbang sebanyak 37 gram, dilarutkan dalam 1 liter akuades dalam tabung erlenmeyer, diaduk sampai homogen dengan menggunakan magnetic stirrer. Media disterilisasi di dalam autoclave pada suhu $121^{\circ} \mathrm{C}$ selama 15 menit; selanjutnya, dituang dalam tabung reaksi sebanyak $7 \mathrm{ml}$ dan ditutup dengan aluminium foil. Media cair BHI siap digunakan sebagai media kultur bakteri (Ortez, 2005).

\section{Pembuatan Media Peremajaan Bakteri}

Nutrient Agar (NA), sebanyak 23 gram, dilarutkan dengan 1 liter akuades di dalam tabung erlenmeyer, dihomogenkan dengan menggunakan magnetic stirrer, dan dituang ke dalam tabung reaksi steril, kemudian ditutup dengan aluminium foil. Media tersebut disterilkan di dalam autoclave pada suhu $121^{\circ} \mathrm{C}$ selama 15 menit. Media yang telah steril dibiarkan pada suhu ruangan selama 30 menit sampai media memadat pada kemiringan $30^{\circ}$.

\section{Pembuatan Lapisan Pembenihan Mueller-Hinton Agar (MHA)}

Mueller-Hinton Agar (MHA) ditimbang sebanyak 38 gram dan dilarutkan dengan 1 liter akuades. Media disterilisasi dalam autoclave pada suhu $121^{\circ} \mathrm{C}$ selama 15 menit. Selanjutnya, media dimasukkan dalam cawan petri sebanyak $10 \mathrm{ml}$ dan dibiarkan hingga mengeras. Pada lapisan berikutnya, dituang media yang sama sebanyak 20 $\mathrm{ml}$. Sedotan dengan diameter $6 \mathrm{~mm}$, yang telah disterilisasi sebelumnya, diletakkan tegak lurus dengan jarak yang seragam satu sama lain. Setelah media agar mengeras sedotan diangkat sehingga terbentuk 5 buah sumur.

\section{Peremajaan Bakteri dan Penanaman Pada Lapisan Pembenihan}

Stok bakteri Eschericia coli, Pseudomonas aeruginosa, Proteus mirabilis, Staphylococcus aureus, dan Staphylococcus saprophyticus diperoleh dari Laboratorium Riset Biomedik Fakultas Kedokteran, Universitas Sam Ratulangi (UNSRAT), Manado. Bakteri diambil dengan menggunakan jarum ose steril, kemudian ditanamkan pada media agar miring, dan menggoresnya dengan cara zig-zag. Bakteri yang telah digores pada media agar diinkubasi dalam inkubator pada suhu $37^{\circ} \mathrm{C}$ selama $1 \times 24$ jam, selanjutnya diambil koloninya dari media agar miring dengan menggunakan jarum ose steril. Kekeruhan bakteri dalam BHI distandarisasi dengan larutan Mc Farland. Koloni yang diambil dimasukkan ke dalam media BHI. Lidi kapas steril dicelupkan ke dalam suspensi bakteri hingga basah. Lidi kapas diperas dengan menekankan pada dinding tabung reaksi bagian dalam, kemudian digores merata pada media MHA (Ortez, 2005).

\section{Pembuatan Kontrol Positif}

Larutan kontrol positif dibuat dengan sediaan antibiotik Chloramphenicol $250 \mathrm{mg}$, kemudian dilarutkan dengan akuades $100 \mathrm{ml}$ hingga homogen menggunakan magnetic stirrer.

\section{Pembuatan Kontrol Negatif}

Kontrol negatif yang digunakan dalam penelitian ini, yaitu pelarut etanol $95 \%$. Digunakannya pelarut etanol sebagai kontrol negatif karena tidak memberikan pengaruh terhadap aktivitas daya hambat.

\section{Pengujian Aktivitas Antibakteri}

Dalam penelitian ini, metode yang digunakan yaitu metode Kirby-Bauer yang dimodifikasi oleh Nainggolan dalam Posangi dan Bara (2014) dengan menggunakan sumuran. Sumur yang berbeda diisi dengan larutan ekstrak spons $A$. tubulata dan Phyllospongia sp. sebanyak $100 \quad \mu l$ dengan konsentrasi larutan ekstrak $0,3 \mathrm{~g} / \mathrm{ml}$ yang dilarutkan dengan etanol $95 \%$; sumur, selanjutnya, diisi dengan kontrol positif, yaitu chloramphenicol yang sudah dilarutkan dengan akuades dan kontrol negatif etanol $95 \%$ serta dilakukan pengulangan. Setelah itu, petri dish diinkubasi pada suhu $37^{\circ} \mathrm{C}$ selama 24 jam.

\section{Uji Kandungan Senyawa dengan Kromatografi Lapis Tipis (KLT)}

Ekstrak A. tubulata yang sudah dievaporasi dilarutkan kembali dengan pelarut yang sesuai, 
yaitu etil asetat:etanol:air (30:5:1); sedangkan ekstrak Phyllospongia sp. dilarutkan dengan kloroform:etanol (8:2). Sebanyak $2 \mu 1$ larutan sampel ditotolkan pada fase diam, yaitu silica gel $\mathrm{GF}_{254}$, dan dielusi dengan fase gerak kloroform:metanol (9:1). Plat KLT dikeringanginkan, kemudian pemisahan diamati di bawah lampu Ultra Violet $254 \mathrm{~nm}$.

\section{Teknik Bioautografi}

Teknik bioautografi digunakan dalam penelitian ini; hal ini dilakukan untuk mendeteksi bercak pada kromatogram dari hasil kromatografi lapis tipis yang mempunyai aktivitas sebagai antibakteri. Bioautografi dalam uji aktivitas antibakteri dapat dilakukan dengan berbagai metode, yaitu bioautografi kontak, bioautografi agar overlay dan bioautografi langsung (Choma, 2005). Pada penelitian ini, digunakan teknik bioautografi kontak yang dilakukan dengan meletakkan lempengan kromatogram hasil elusi dari ekstrak yang diuji di atas media padat yang telah diinokulasi dengan bakteri uji. Adanya aktivitas antibakteri dari senyawa uji ditandai dengan adanya zona bening pada senyawa aktif.

Sebanyak $2 \mu$ ditotolkan pada plat KLT, dielusi dalam bejana dengan fase gerak kloroform: metanol (9:1). Plat KLT yang telah dielusi ditempelkan pada media MHA yang telah diinokulasi dengan $200 \mu \mathrm{l}$ bakteri; didiamkan selama 1 jam, diberi tanda pada bagian bawahnya, kemudian plat diangkat. Kemudian, diinkubasi pada suhu $37^{\circ} \mathrm{C}$ selama 24 jam. Bila ada bercak pada

kromatogram yang memiliki aktivitas antibakteri, maka dengan cara difusi akan terbentuk zona bening yang merupakan zona hambat. Kemudian Plat KLT yang ada dipotong dan dibawa ke Laboratorium Analisis Farmasi Fakultas MIPA UNSRAT untuk diuji dengan menggunakan spektrofotometer UV-Vis.

Isolat yang ada dikeluarkan dan dilarutkan dalam metanol kemudian di vortex dan disentrifus di mana terbentuk endapan dan supernatan. Supernatan dituang ke tabung reaksi yang lain. Supernatan yang ada ditambahkan lagi metanol. Pengulangan sampai 3 kali. Kemudian supernatan yang ada diuji pada spektofotometer UV-Vis.

\section{Pengamatan dan Pengukuran}

Pengamatan dilakukan setelah 24 jam dan 48 jam masa inkubasi. Zona bening merupakan petunjuk kepekaan bakteri terhadap bahan antibakteri yang digunakan sebagai bahan uji dan dinyatakan dengan luas zona hambat. Berdasarkan penggolongan Davis and Stout (1971), zona hambat dikategorikan sebagai kekuatan daya antibakteri. Zona hambat yang terbentuk di sekitar sumur diukur diameternya dengan menggunakan mistar berskala dalam satuan milimeter $(\mathrm{mm})$.

\section{HASIL DAN PEMBAHASAN}

Dalam penelitian ini, pengujian daya hambat dilakukan dengan mengukur diameter zona hambat yang dihasilkan pada media yang mengandung 5

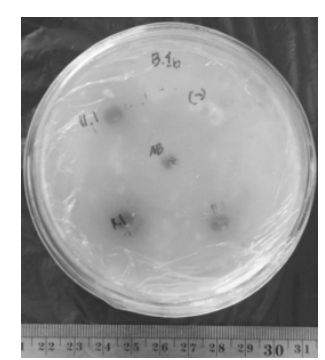

P. aeruginosa

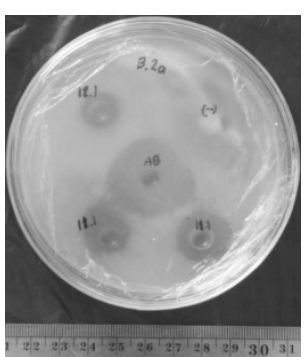

P. mirabilis

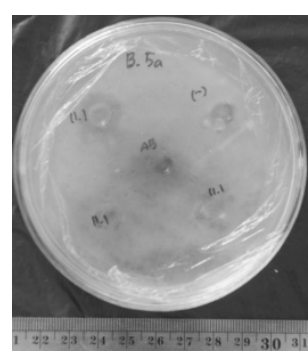

S. aureus

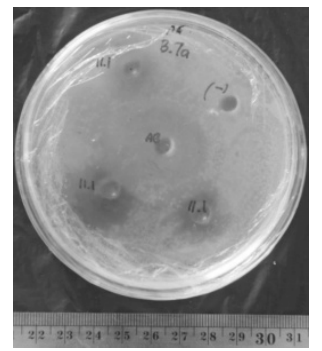

E. coli

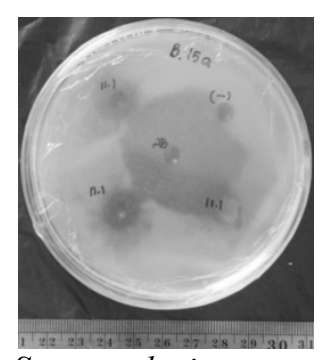

S. saprophyticus

Gambar 1. Zona hambat Ekstrak spon Agelas tubulata pada pengamatan $1 \times 24$ Jam terhadap pertumbuhan bakteri $P$. aeruginosa, P. mirabilis, S. aureus, E. coli dan $S$. saprophyticus.

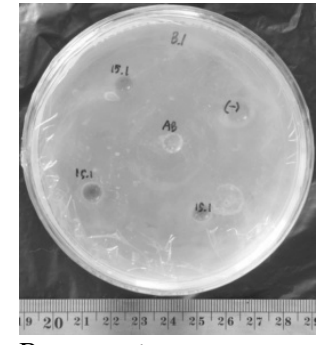

$P$. aeruginosa

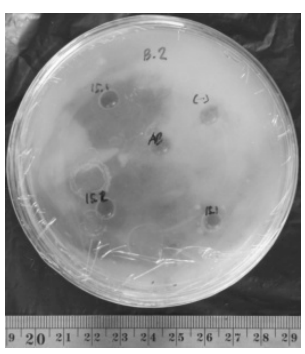

P. mirabilis

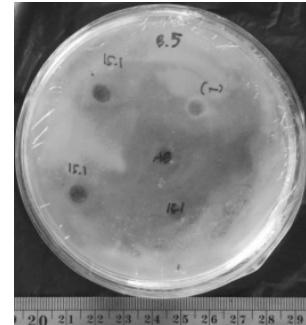

S. aureus

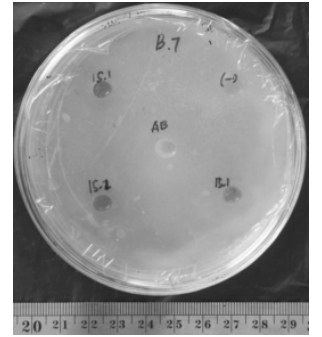

E. coli

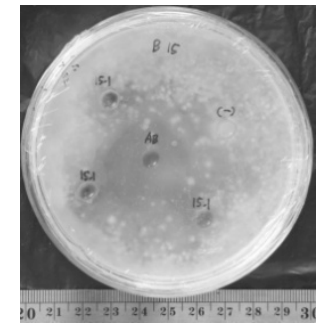

S. saprophyticus

Gambar 2.Zona hambat ekstrak spons Phyllospongia sp. pada pengamatan $1 \times 24$ Jam terhadap pertumbuhan bakteri $P$. aeruginosa, $P$. mirabilis, $S$. aureus, E.coli dan S. saprophyticus. 
bakteri, yaitu $P$. aeruginosa, $P$. mirabilis, $S$. aureus, $E$. coli dan $S$. saprophyticus setelah dilakukan inkubasi selama 24 jam pada suhu $37^{\circ} \mathrm{C}$. Pengujian daya hambat dilakukan dengan mengukur diameter zona hambat yang dihasilkan pada media yang mengandung 5 bakteri setelah diinkubasi selama 24 jam pada suhu $37^{\circ} \mathrm{C}$.

Bakteri yang digunakan pada penelitian ini bersifat Gram positif dan Gram negatif. Untuk $P$. aeruginosa, P. mirabilis, E. coli bersifat Gram negatif dan untuk $S$. aureus dan $S$. saprophyticus bersifat Gram positif. Penggunaan bakteri Gram negatif pada penelitian ini dengan alasan karena sejauh ini pengendalian infeksi Gram negatif sering kali menjadi kendala dalam dunia kedokteran modern. Hal ini diakibatkan oleh karakteristik bakteri kelompok Gram negatif yang memiliki dinding peptidoglikan yang cukup padat dan kompak sehingga menghambat proses internalisasi senyawa obat untuk mampu mempengaruhi mekanisme selular dari bakteri; di samping itu, karena adanya efflux-pump mechanism, yaitu suatu mekanisme untuk mengeluarkan senyawa-senyawa yang tidak dibutuhkan dalam proses-proses biotransformasi seluler bakteri melalui sistem sekresi mereka (Poole, 2007; Posangi dan Bara,
2014).

Ekstrak A. tubulata dan Phyllospongia sp. memiliki daya hambat terhadap bakteri $P$. aeruginosa, P. mirabilis, $S$. aureus, E. coli dan $S$. saprophyticus yang telah diinkubasi selama 24 jam pada suhu $37^{\circ} \mathrm{C}$ (Gambar 1 dan Gambar 2).

Data yang diperlihatkan pada Tabel 1 menunjukkan, bahwa zona hambat ekstrak $A$. tubulata berbeda-beda terhadap kelima jenis bakteri uji. Zona hambat yang dibentuk dari ekstrak tersebut terhadap bakteri $P$. aeruginosa berkisar $15,75 \mathrm{~mm}, P$. mirabilis berkisar $14,83 \mathrm{~mm}, S$. aureus berkisar 13,50, E. coli berkisar $18,92 \mathrm{~mm}$, dan $S$. saprophyticus berkisar $14,00 \mathrm{~mm}$. Selanjutnya, pengukuran zona hambat pada Tabel 1 dibuat dalam bentuk diagram yang disajikan seperti pada Gambar 3. Nampak, ekstrak A. tubulata memiliki daya hambat dengan spektrum yang lebih luas dibandingkan ekstrak Phyllospongia sp.

Nilai rerata pengukuran zona hambat ekstrak Phyllospongia sp. terhadap bakteri $P$. aeruginosa, P. mirabilis, $S$. aureus, E. coli dan $S$. saprophyticus disajikan dalam Tabel 1.

Data yang diperlihatkan pada Tabel 1 menunjukkan bahwa zona hambat ekstrak Phyllospongia sp. berbeda-beda terhadap kelima

Tabel 1. Rerata diameter zona hambat ekstrak spons Agelas tubulata dan Phyllospongia sp. pada pertumbuhan bakteri Pseudomonas aeruginosa, Proteus mirabilis, Staphylococcus aureus, Eschericia coli dan Staphylococcus saprophyticus.

\begin{tabular}{llllll}
\hline \multirow{2}{*}{ Spesis Spons } & \multicolumn{5}{c}{ Bakteri } \\
\cline { 2 - 6 } & \multicolumn{1}{c}{ P. aeruginosa } & \multicolumn{1}{c}{ P. mirabilis } & S. aureus & E. coli & S. saprophyticus \\
\hline Agelas tubulata & $15,75 \pm 4,02$ & $14,83 \pm 2,73$ & $13,5 \pm 3,61$ & $18,92 \pm 2,99$ & $14,00 \pm 1,52$ \\
Phyllospongia sp. & $11,25 \pm 0,92$ & $29,58 \pm 8,41$ & $16,92 \pm 6,14$ & $10,58 \pm 1,26$ & $13,67 \pm 2,86$ \\
Antibiotik & 36,00 & 30,00 & 20,00 & 57.25 & 40,00 \\
\hline
\end{tabular}

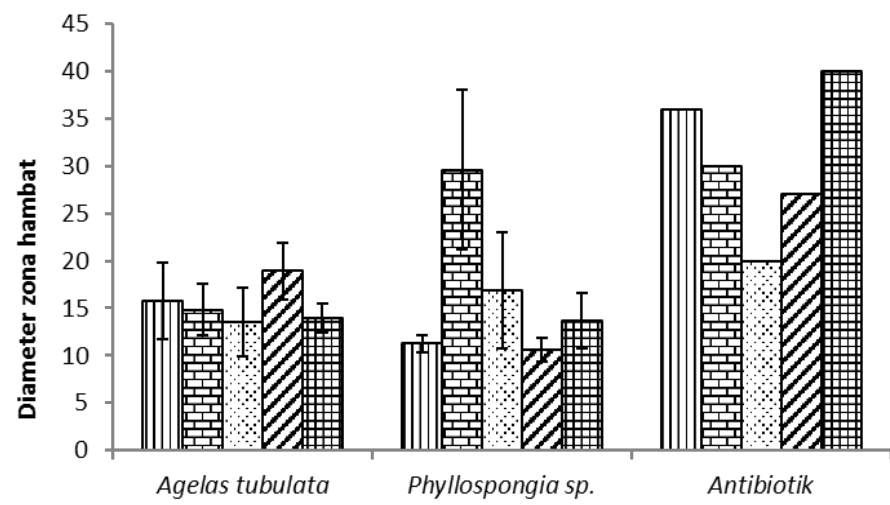

$\square P$. aeruginosa

巴P. mirabilis

O. S. aureus

\. coli

田S. saprophyticus

Gambar 5. Grafik histogram rerata diameter zona hambat ekstrak spons Agelas tubulata dan Phyllospongia sp. pada pengamatan $1 \times 24$ jam terhadap pertumbuhan bakteri $P$. aeruginosa, $P$. mirabilis, S. aureus, E. coli dan S. saprophyticus. 
jenis bakteri uji. Zona hambat yang dibentuk dari ekstrak tersebut terhadap bakteri $P$. aeruginosa berkisar $11,25 \mathrm{~mm}$, terhadap bakteri $P$. mirabilis berkisar $29,58 \mathrm{~mm}$, terhadap $S$. aureus berkisar $16,92 \mathrm{~mm}$, terhadap $E$. coli berkisar $10,58 \mathrm{~mm}$, terhadap S. saprophyticus berkisar $13,67 \mathrm{~mm}$. Selanjutnya, pengukuran zona hambat pada Tabel 1 dibuat dalam bentuk diagram yang disajikan seperti pada Gambar 3. Nampak, ekstrak Phyllospongia sp. lebih spesifik membunuh bakteri $P$. mirabilis.

\section{Uji Bioautografi}

Berdasarkan hasil uji bioautografi senyawa aktif yang terdapat pada $A$. tubulata memiliki nilai Rf 0,1 dengan menggunakan fase gerak etil asetat:etanol:air (30:5:1). Eluen ini lebih bersifat polar dibandingkan dengan eluen yang digunakan pada ekstrak Phyllospongia sp. yang menggunakan kloroform:etanol (9:1). Senyawa aktif pada ekstrak Phyllospongia sp. memiliki nilai Rf 0,65. Hasil dari uji bioautografi ini dilanjutkan dengan uji Spektrofotometer UV-Vis.

\section{Uji Spektrofotometer}

Hasil bercak pada plat KLT (Gambar 4) yang memiliki aktifitas antibakteri dipotong dan dilarutkan kembali dengan metanol selanjutnya dibaca dengan spektrofotometer UV-Vis (Gambar 5). Gambar 5 menunjukkan, bahwa senyawa antibakteri yang terdapat pada ekstrak $A$. tubulata memiliki serapan UV maksimum pada panjang gelombang $275 \mathrm{~nm}$; sedangkan senyawa antibakteri pada ekstrak Phyllospongia sp. memiliki serapan UV maksimum pada panjang gelombang $285 \mathrm{~nm}$.

Kisaran panjang gelombang senyawa antibakteri pada kedua spons berada pada 270-285 nm. Hal ini memberikan bukti, bahwa kedua senyawa aktif yang terdapat pada spons $A$. tubulata dan Phyllospongia sp. memiliki gugus fungsi siklo heksana. Senyawa aktif dengan gugus fungsi ini biasanya terdapat di alam pada struktur senyawa terpenoid dan flavonoid dengan aktifitas antibakteri yang kuat (Manasa, 2014; Bara et al., 2013; Walker et al., 1952; Pinheiro and Goncalo, 2012; Tyukavkina et al., 1970; Bara et al., 2013; TalebContini et al., 2003 dan Silverstein et al., 2005).

\section{KESIMPULAN}

Kesimpulan dari penelitian ini adalah sebagai berikut:

1. Ekstrak A. tubulata dan Phyllospongia sp. mempunyai aktivitas terhadap bakteri $P$. aeruginosa, P. mirabilis, $S$. aureus, E. coli dan S. saprophyticus.

2. Ekstrak A. tubulata memiliki daya hambat dengan spektrum yang lebih luas dibandingkan ekstrak Phyllospongia sp. sedangkan ekstrak Phyllospongia sp. memiliki spesifitas terhadap bakteri P. mirabilis.

3. Dari hasil penelitian melalui teknik bioautografi, serapan terjadi pada panjang gelombang 275 A. tubulata dan $285 \mathrm{~nm}$ untuk Phyllospongia sp.

\section{REFERENSI}

BARA, R., ALY, A. H., PRETSCH, A., WRAY, V., WANG, B., PROKSCH, P., DEBBAB, A. (2013). "Antibiotically Active Metabolites from Talaromyces wortmannii, an endophyte of Aloe vera." The Journal of Antibiotics 10.1038/ja.2013.28.

BARA, R. A., ZERFAß, I., LAI, D., LIN, W., DEBBAB, A., BRÖTZ-OESTERELT, H., PROKSCH, P. (2013). "New Natural Product from Botryosphaeria australis, an Endophyte from Mangrove Avicennia marina." Squalen Bulletin of Marine \& Fisheries Postharvest \& Biotechnology 8(3): 139-145.

BLUNT, J.W., COPP, B.R., KEYZERS, R.A., MUNRO, M.H.G. and PRINSEP, M.R. 2012. Marine natural products. Nat. Prod. Rep. 29:

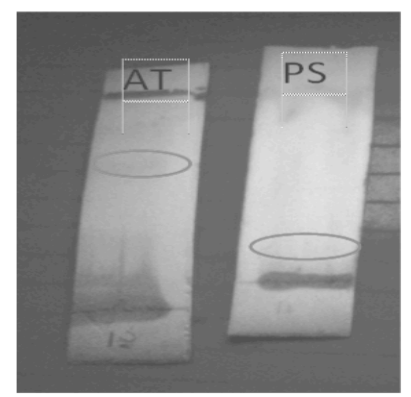

Gambar 4. Hasil Kromatografi Lapis Tipis dari ekstrak Agelas tubulata dan Phyllospongia sp. terhadap bakteri Staphylococcus aureus. 


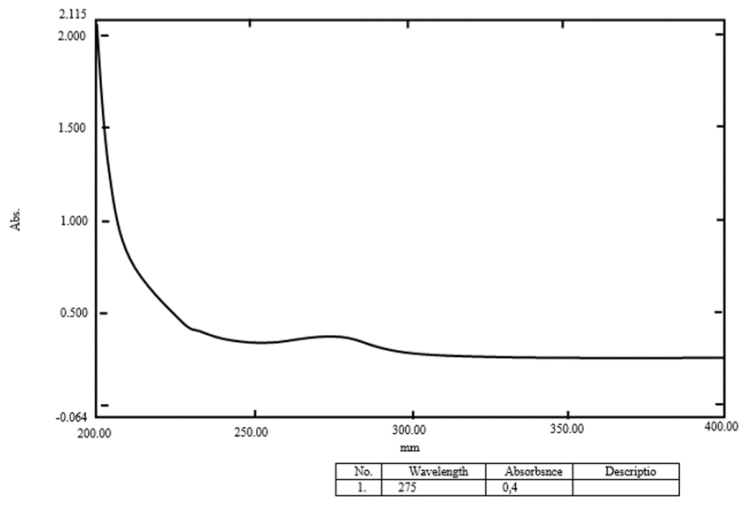

a. Agelas tubulata

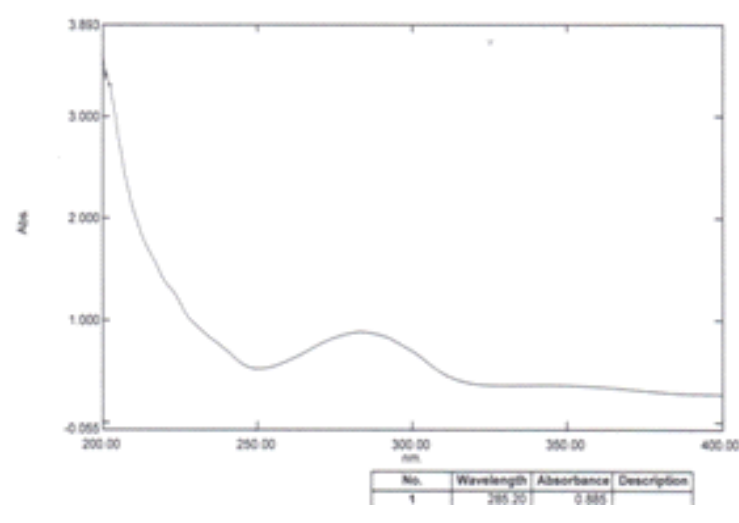

b. Phyllospongia sp.

Gambar 5. Hasil uji spektrofotometer ultra violet

144-222, and previous reports in this series.

BLUNT, J.W.; COPP, B.R.; MUNRO, M.H.G.; NORTHCOTE, P.T.; PRINSEP, M.R., 2004. Marine Natural products. Nat Prod Rep. 21,149.

CHOMA, I. 2005. The use of thin layer chromatography with direct bioautography for antymicrobial analysis. Journal of Chromatography $A$.

DAVIS, W.W. and STOUT, T. R. 1971. Disc Plate Method of Microbiological Assay.

DENNING, D. 2006. Branches on the tree of Life: Sponges. Retrieved Februari 23, 2016, from http://ebiomedia.com/prod/BOsponges.html.

MANASA, G. 2014. Structural Elucidation of Terpenoids by Spectroscopic Techniques. Journal of Chemical and Pharmaceutical Sciences. ISSN: 0974-2115.

ORTEZ, J. 2005. Disk Diffusion Testing in Manual of Antimicrobial Susceptibility testing. Marie B. Coyle (Coord. Ed). American society for Microbiology.

PINHEIRO, P and GONCALO J. 2012. Structural Analysis of Flavonoids and Related Compounds-A Review of Spectroscopic Applications. Technical University of Lisbon. Portugal.

POOLE, K. 2007. Efflux Pumps as Antimicrobial Resistance Mechanisms. Annals of Medicine, 39(3):162-176.
POSANGI, J., Bara, R. 2014. Analisis Aktivitas dari Jamur Endofit yang terdapat dalam Tumbuhan Bakau Avicennia marina di Tasik Ria Minahasa. Jurnal Pesisir Dan Laut Tropis , 1(1)30-38.

ROMPAS, R. 2011. Farmakognosi Laut (Sumber Baru ekonomi Kelautan). Jakarta: Dewan Kelautan Indonesia.

SILVERSTEIN, R.M., WEBSTER, F.X., \& KIEMBLE, D.J. (2005). Spectrometric Identification of Organic Compounds. 7 ed. USA: John Wiley and Sons.

TALEB-CONTINI, S. H., SALVADOR, M. J., WATANABE, E., ITO, I. Y. OLIVEIRA, D. C. R. D. (2003). "Antimicrobial Activity of Flavonoids and Steroids Isolated from Two Chromolaena Species". Brazilian Journal of Pharmaceutical Sciences 39(4).

TYUKAVKINA, N.A., POGODAEVA N.N. and LUTSKI V. I (1970). Ultraviolet absorption of Flavonoids. Irkutstak Institute of Organic Chemistry, Siberian Division. Khimiya Prirodynkh Soedinenli, Vol. 6, No.1. pp 24-27.

WALKER D., ROBERT, JR. and HAWKINS J. E. 1952. The Ultraviolet Absorption Spectra of Some Terpene Hydrocarbons. Journal of the American Chemical Society (ACS) Publications.

Diterima: 25 Februari 2016 Disetujui: 18 April 2016 